\title{
Persepsi Masyarakat Mengenai Olahraga Berenang Di Masa Covid-19
}

\section{Society's Perspective of Time Swimming Sports Covid-19}

\author{
Muhamad Yusuf Nursyamsi', Yonatan Julian Ansell ${ }^{2}$ \\ ${ }^{1,2}$ Program studiPJKR, STKIP Pasundan, Jalan Permana No. 32B Kota Cimahi, Jawa Barat, \\ 40553, Indonesia
}

\begin{abstract}
Abstrak
Penelitian ini dilakukan untuk mengetahui bagaimana pandangan masyarakat terhadap aktivitas olahraga berenang selama masa pandemi covid - 19 ini, apakah aktivitas ini dianggap positif oleh masyarakat atau masyarakat beranggapan bahwa ini merupakan hal negatif, kemudian apakah olahraga ini tetap eksis dan tetap dilakukan masyarakat atau cenderung menurun dibandingkan ketika sebelum masa pandemi covid - 19. Metodenya menggunakan metode survei. Data diperoleh dengan menggunakan angket langsung dan tertutup mengenai persepsi masyarakat melalui google form (digital) yang dibagikan kepada para responden yang dipilih menggunakan teknik Accidental Sampling yang yang berjumlah total 30 responden. Uji Validitas dilakukan dengan menggunakan analisis korelasi rumus Product Moment dari Pearson dengan hasil 17 butir instrumen yang valid. Penulis memperoleh kesimpulan yang dapat diambil dari penelitian ini. Dari hasil penelitian menunjukkan bahwa adanya persepsi masyarakat mengenai olahraga berenang di masa covid - 19. Hal ini membuktikan bahwa masih adanya suatu dorongan yang membuat masyarakat berolahraga berenang walaupun masih dalam konidisi pandemi covid - 19. Rasa khawatir untuk melakukan olahraga berenang di masa covid - 19 memang masih ada di masyarakat. Karena tidak bisa dipungkiri di dalam keadaan pandemi covid -19 masyarakat tidak bisa seenaknya saja untuk menjalankan aktivitas di luar rumah. Khususnya ketika menjalankan aktivitas yang berada di tempat umum yang kita tidak tahu kondisi akan bertemu dengan siapa saja, apakah orang tersebut sehat atau tidak sehat, apakah orang lain tersebut membawa virus atau tidak.
\end{abstract}

Kata kunci: Persepsi Masyarakat, Olahraga Berenang, Covid-19

\begin{abstract}
This study was conducted to find out how society's view of sports swimming during this covid pandemic -- 19, whether this activity is considered positive by society or society thinks that this is a negative thing, - then whether this sport continues to exist and continues to be done by society or tends to decline compared to before the covid pandemic - 19. The method is using a survey method. Data is obtained using direct and closed public perception angles through Google form (digital) shared with selected respondents using Accidental Sampling techniques of a total of 30 respondents. Validity tests are performed using Pearson's complicated Product Moment correlation analysis with 17 valid instrument details. Penulis memperoleh kesimpulan yang dapat diambil dari penelitian ini. Research has shown that there is a public perception of swimming sports during the covid period - 19. This proves that there is still an incentive that makes people practice swimming even though they are still in a covid pandemic condition - 19. Worried about doing swimming sports in the covid era - 19 are still in society. Because it can't be counted in a covid pandemic -19 society can't simply run activities outside the house. Especially when you run activities in a public place that we don't know the conditions will meet with anyone, whether they're healthy or not, whether they're carrying a virus or not.
\end{abstract}

Keywords: Public Perception, Swimming, Covid-19

Correspondence author Muhamad Yusuf Nursyamsi, Yonatan Julian Ansell, STKIP Pasundan cimahi, Indonesia.

Email: fandey2111@gmail.com/yonatanjul@gmail.com 


\section{PENDAHULUAN}

Olahraga merupakan kegiatan yang hidup berdampingan dengan masyarakat, olahraga tidak pernah lepas dari kehidupan manusia seumur hidupnya. Olahraga merupakan proses sistematik yang berbentuk seluruh aktivitas ataupun usaha yang bisa meningkatkan, serta membina potensi- potensi jasmaniah serta rohaniah perorangan ataupun kelompok masyarakat dalam wujud game, perlombaan/ pertandingan, serta aktivitas jasmani yang intensif buat mendapatkan kesenangan, serta kemenangan dalam kejuaraan (Issom \& Putra, 2018).

(Santosa Giriwijoyo, 2012) mengatakan olahraga adalah serangkaian gerak raga yang teratur dan terencana untuk memelihara gerak (yang berarti mempertahankan hidup) dan meningkatkan kemampuan gerak (yang berarti meningkatkan kualitas hidup) (Kurniawan, 2017). Suryanto Rukmono memandang olahraga sebagai suatu gerak melatih tubuh individu atau kelompok untuk tujuan mendapatkan tubuh yang lebih sehat dan kuat, baik jasmani dan rohani (Noveri et al., 2017). Sedangkan Menurut Seno Gumira Ajidarma, definisi olahraga adalah suatu kegiatan yang menyebabkan tubuh manusia tumbuh sehat dan sebagai ajang kompetisi untuk menunjukan kemampuan seseorang di bidang olah raga (Noveri et al., 2017).

Olahraga renag di indonesia merupakan satu kegiatan yang sering dilakukan oleh masyarakat luas baik dari kalangan anak-anak sampai manula, karena sudah diketahui memberikan manfaat untuk kesehatan maupun meningkatkan kebugaran jasmani dan meningkatkan biomotorik. Sedangkan menurut Rothig at al dalam Syafruddin (2011:21) olahraga adalah suatu proses pengolahan atau penerapan materi olahraga seperti keterampilan-keterampilan gerakan dalam bentuk pelaksanaan yang berulang-ulang dan melalui tuntutan yang bervariasi. Olahraga yang relatif lama memerlukan energi yang juga relatif besar. Pada awal olahraga penggunaan glukosa akan sangat tinggi untuk sumber energi olahraga(Lesmana \& Broto, 2018). Eri Barlian (2013: 43) mengemukakan, setidaknya ada 6 alasan masyarakat mau berolahraga, yaitu: 1) Untuk bersenang-senang dan kegembiraan, 2) Untuk melepaskan ketegangan psikis, 3) Untuk dapat berhubungan dengan orang lain, 4) Untuk kepentingan kebanggaan kelompok, 5) Untuk memelihara kesehatan, 6) Untuk keperluan praktis.

Renang adalah aktivitas fisik di air yang membuat badan mengambang dan bergerak dari satu titik ke titik yang lain dengan menggunakan anggota tubuh dan koordinasi gerakan anggota tubuh. Menurut (Hamsa, 2015). Mengukakan "renang adalah gerakan saat kita berpindah dari satu tempat ke tempat lainnya didalam air, baik di 
sungai, danau, laut, ataupun kolam renang" (Ishak et al., 2020). Menurut Kahfi (2012:17) "Renang adalah salah satu cabang olahraga yang bisa diajarkan pada semua umur, baik itu anak-anak maupun orang dewasa. bayi yang berumur beberapa bulan juga sudah bisa di ajarkan renang" (Ishak, 2017). Renang merupaka olahraga yang selalu eksis dan populer di tengah - tengah masyarakat (Pratiwi, 2015).

Istilah persepsi dipakai untuk menunjukkan pandangan, pendapat individu, masyarakat, dan mass media. Couto (2010: 12), mendefinisikan persepsi adalah proses pemahaman ataupun pemberian makna atas suatu informasi terhadap stimuli-luar (rangsang dari luar). Sedangkan menurut Walgito (2010: 99), persepsi merupakan suatu proses yang didahului oleh proses penginderaan, yaitu merupakan proses diterimanya stimuilus oleh individu melalui alat indera atau juga disebut proses sensoris. Sejalan dengan itu Rivai dan Mulyadi (2012: 236) mengemukakan, persepsi adalah suatu proses yang ditempuh individu untuk mengorganisasikan dan menafsirkan kesan-kesan indera mereka agar memberikan makna bagi lingkungan mereka. Sementara itu Wiraman (2014 : 751) mengatakan bahwa persepsi merupakan proses mengidentifikasi, mengorganisasi, dan menginterpretasikan informasi yang ditangkap oleh panca indera untuk melukiskan dan memahaminya. Berdasarkan keempat pendapat tersebut dipahami bahwa persepsi merupakan suatu kegitan yang melibatkan panca indera dalam proses mengidentifikasi, mengorganisasi dan menginterpretasikan informasi.

Persepsi dapat disimpulkan sebagai suatu proses penginderaan, stimulus yang diterima oleh individu melalui alat indera yang kemudian di interpretasikan sehingga individu dapat memberikan pandangan, memahami dan dapat mengartikan tentang stimulus yang diterimanya. Proses menginterpretasikan ini biasanya dipengaruhi oleh pengalaman dan proses belajar individu. (Ramadani, 2014) berolahraga untuk menjaga imun tubuh namun di sisi lain juga fasilitas olahraga berenang yang ada di masyarakat bersifat umum dan masyarakat tidak bisa menjaga kesterilan kolam sepenuhnya. Berbagai orang bisa saja datang ke fasilitas olahraga berenang dan masuk ke kolam renang, hal ini yang tidak bisa dihindari oleh masyarakat. Maka dari itulah beberapa pandangan mengenai kekhawatiran untuk melakukan olahraga berenang di masa covid - 19 ini tidak bisa lepas dari masyarakat.

Dari paradigma yang terjadi penulis begitu tertarik untuk meneliti pertanyaan dan angapan di masyarakat yang luas saat ini, Maka Penulis Melakukan Suatu Penelitian Dengan Judul "Persepsi Masyarakat Mengenai Olahraga Berenang Di Masa Covid - 19" 


\section{METODE}

Metode penelitian yang digunakan dalam penelitian ini adalah metode kuantitatif dengan pendekatan survei. populasi dalam penelitian ini adalah pengunjung Kolam Renang Muara. Teknik sampling yang digunakan yaitu accidental sampling dengan jumlah sampel 30 orang pengunjung kolam berusia sekitar 14 tahun - 55 tahun di kolam renang muara.

Penulis akan menggunakan angket melalui google form (digital) atau kuisioner langsung. Kuesioner langsung, merupakan jawaban dari responden untuk menjawab mengenai dirinya sendiri (Winarno, 2013).

Adapun langkah yang akan ditempuh dalam analisis data pada penelitian ini menggunakan rumus statistik diantaranya sebagai berikut: 1. Menghitung rata-rata (Mean). 2. Menghitung simpangan baku. 3. Teknik persentase.

\section{HASIL DAN PEMBAHASAN}

\section{Hasil}

Deskripsi data dalam penelitian ini bertujuan untuk menggambarkan hasil data kuantitatif. Untuk memperoleh data mengenai persepsi masyarakat mengenai olahraga berenang di masa covid - 19 dapat diperoleh dari hasil angket melalui google form (digital) yang disebarkan kepada masyarakat pengunjung kolam renang berjumlah 30 orang. Kemudian hasil ini dicocokkan pada tabel distribusi frekuensi skor data Mean.

Tabel 1

Distribusi frekuensi skor data Mean

\begin{tabular}{|c|c|c|c|c|}
\hline Interval & $f_{i}$ & $\boldsymbol{X}_{i}$ & $f_{i} X_{i}$ & Mean \\
\hline $41-45$ & 2 & 43 & 86 & \\
\hline $46-50$ & 5 & 48 & 240 & $\bar{X}=\frac{\sum f_{i} x_{\tilde{i}}}{f_{\tilde{i}}}$ \\
\hline $51-55$ & 8 & 53 & 424 & \\
\hline $56-60$ & 13 & 58 & 754 & $\bar{X}=\frac{1630}{30}$ \\
\hline $61-65$ & 2 & 63 & 126 & $\bar{X}=54,333$ \\
\hline JUMLAH & 30 & 265 & 1630 & \\
\hline
\end{tabular}

Dengan demikian rata - rata yang diperoleh dari angket persepsi melalui google form (digital) adalah 54,333

Menghitung Simpangan Baku 
Tabel 2

Distribusi frekuensi skor data Simpangan Baku

\begin{tabular}{ccccccc}
\hline Interval & $\boldsymbol{X}_{\boldsymbol{i}}$ & $\boldsymbol{f}_{\boldsymbol{i}}$ & $\boldsymbol{f}_{i} \boldsymbol{X}_{i}$ & $\boldsymbol{X}_{i}-\overline{\boldsymbol{X}}$ & $\left(\boldsymbol{X}_{i}-\overline{\boldsymbol{X}}\right)^{\mathbf{2}}$ & $\boldsymbol{f}_{i}\left(\boldsymbol{X}_{i}-\overline{\boldsymbol{X}}\right)^{\mathbf{2}}$ \\
\hline $\mathbf{4 1}-\mathbf{4 5}$ & 43 & 2 & 86 & -11.333 & 128.445 & 256.891 \\
\hline $\mathbf{4 6}-\mathbf{5 0}$ & 48 & 5 & 240 & -6.333 & 40.111 & 200.559 \\
\hline $\mathbf{5 1}-\mathbf{5 5}$ & 53 & 8 & 424 & -1.333 & 1.777 & 14.223 \\
\hline $\mathbf{5 6}-\mathbf{6 0}$ & 58 & 13 & 754 & 3.666 & 13.443 & 174.771 \\
\hline $\mathbf{6 1}-\mathbf{6 5}$ & 63 & 2 & 126 & 8.666 & 75.109 & 150.219 \\
\hline & JUMLAH & 30 & 1630 & -6.667 & 258.889 & 796.666 \\
\hline
\end{tabular}

Dengan demikian Simpangan baku yang diperoleh dari angket persepsi masyarakat melalui google form (digital) adalah 4,23.

Menghitung skor untuk setiap item dengan rekapitulasi pengumpulan data angket dari data 30 responden berdasarkan data yang diperoleh dan menghitung rata- rata skor dengan jumlah skor ideal atau skor tertinggi untuk semua item 4 × $30=120$ dan jumlah skor terendah adalah 1 x $30=30$.

Setelah dipersentasekan maka nilai tersebut dimasukan ke dalam kriteria perhitungan persentase. Menurut Effendi dan Manning, berikut ini kriteria perhitungan persentase (Heni Hendrawati,2016) :

Tabel 3

Kriteria Penilaian Skor

\begin{tabular}{cl}
\hline Persentase & Keterangan \\
\hline $0 \%$ & Tidak ada \\
\hline $1 \%-24 \%$ & Sebagian kecil \\
\hline $25 \%-49 \%$ & Kurang dari setengahnya \\
\hline $50 \%$ & Setengahnya \\
\hline $51 \%-74 \%$ & Lebih dari setengahnya \\
\hline $75 \%-99 \%$ & Sebagian besar \\
\hline $\mathbf{1 0 0 \%}$ & Seluruhnya
\end{tabular}

Dari hasil perhitungan skor dari setiap item soal maka penulis memperoleh hasil perhitungan jawaban responden dari setiap indikator aspek - aspek persepsi masyarakat, sebagai berikut: 
a. Perasaan

Tabel 4

Frekuensi Indikator Perasaan

\begin{tabular}{cccc}
\hline No & Kategori & Frekuensi & Presentase (\%) \\
\hline $\mathbf{1}$ & Sangat Setuju & 68 & $32.38 \%$ \\
\hline $\mathbf{2}$ & Setuju & 86 & $40.95 \%$ \\
\hline $\mathbf{3}$ & Agak Tidak Setuju & 35 & $16.67 \%$ \\
\hline $\mathbf{4}$ & Tidak Setuju & 21 & $10.00 \%$ \\
\hline & Jumlah & 210 & $100 \%$ \\
\hline
\end{tabular}

Berikut ini disajikan data responden berdasarkan pendapatnya mengenai perasaan masyarakat dalam bentuk grafik.

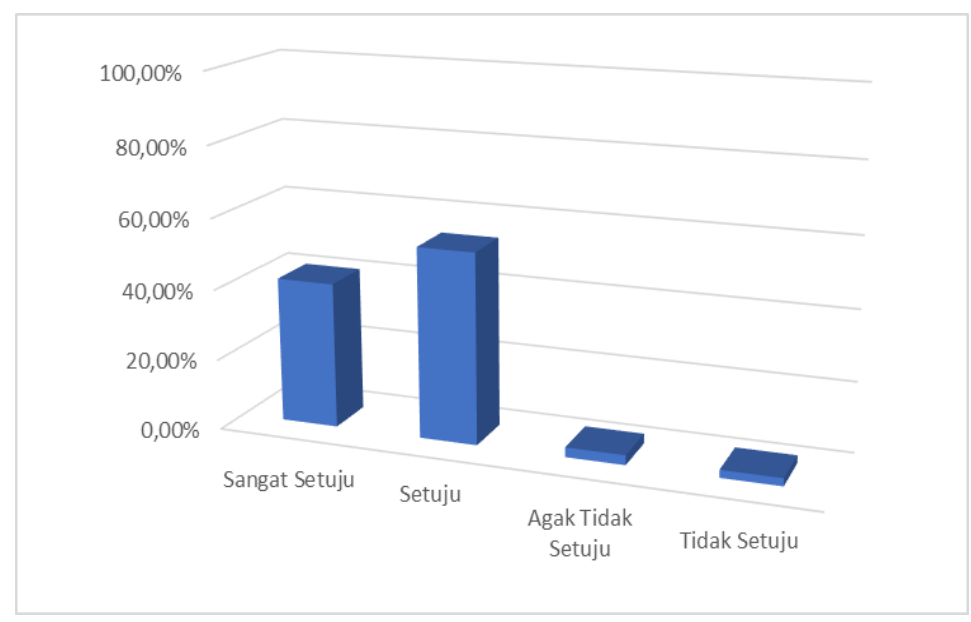

Grafik 1

Frekuensi Indikator Perasaan

Harapan

Tabel 5

Frekuensi Indikator Harapan

\begin{tabular}{cccc}
\hline No & Kategori & Frekuensi & Presentase (\%) \\
\hline $\mathbf{1}$ & Sangat Setuju & 65 & $43.33 \%$ \\
\hline $\mathbf{2}$ & Setuju & 75 & $50.00 \%$ \\
\hline $\mathbf{3}$ & Agak Tidak Setuju & 7 & $4.67 \%$ \\
\hline $\mathbf{4}$ & Tidak Setuju & 3 & $2.00 \%$ \\
\hline & Jumlah & 150 & $100 \%$ \\
\hline
\end{tabular}


Berikut ini disajikan data responden berdasarkan pendapatnya mengenai harapan masyarakat dalam bentuk grafik.

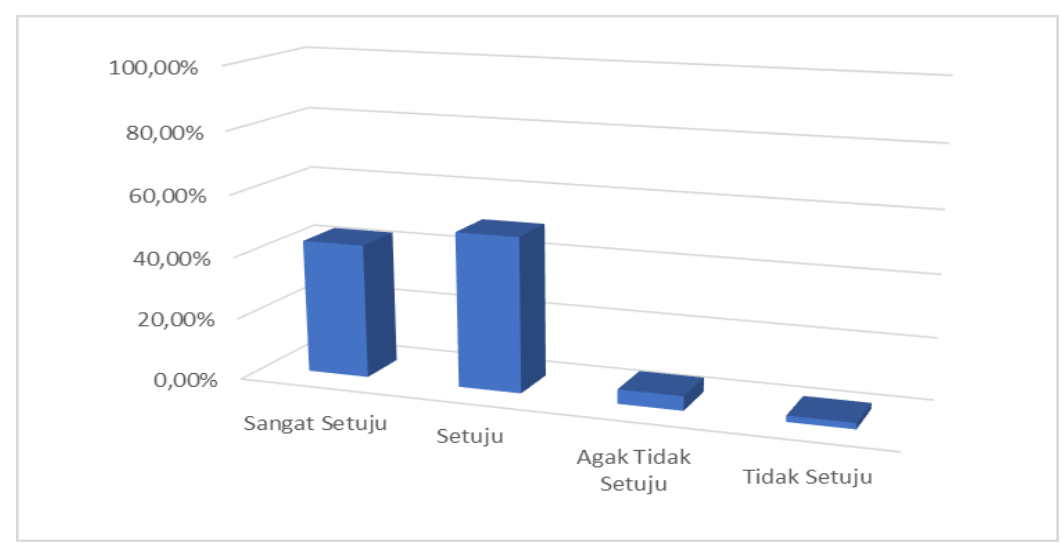

Grafik 2

Frekuensi Indikator Harapan

Tabel 6

Frekuensi Persepsi Masyarakat Mengenai Olahraga Berenang di Masa Covid - 19

\begin{tabular}{cccc}
\hline No & Kategori & Frekuensi & Presentase (\%) \\
\hline $\mathbf{1}$ & Perasaan & 68 & $32.85 \%$ \\
\hline $\mathbf{2}$ & Motif & 74 & $35.75 \%$ \\
\hline $\mathbf{3}$ & Harapan & 65 & $31.40 \%$ \\
\hline & Jumlah & 207 & $100 \%$ \\
\hline
\end{tabular}

Berikut ini disajikan data responden berdasarkan persepsi masyarakat mengenai olahraga berenang di masa covid - 19 yang disajikan dalam bentuk grafik. 


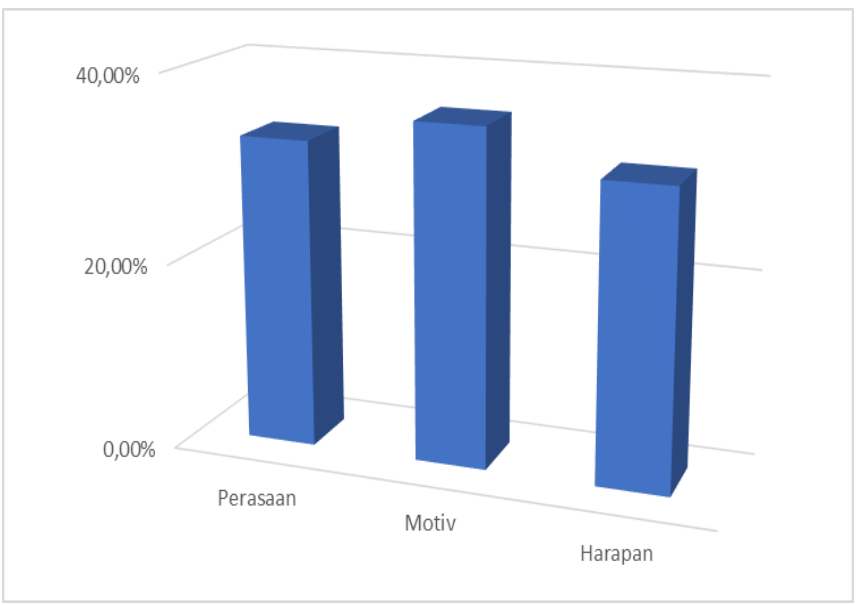

Grafik 3

Frekuensi Persepsi Masyarakat Mengenai Olahraga Berenang di Masa Covid - 19

\section{Pembahasan}

Penelitian ini bertujuan untuk mengetahui persepsi masyarakat mengenai olahraga berenang di masa covid - 19. Berdasarkan hasil analisis deskriptif dan statistika yang telah dilakukan peneliti diperoleh hasil sebagai berikut:

1. Persepsi masyarakat mengenai olahraga berenang di masa covid - 19 nilai tertinggi adalah 62 dan nilai terendah 41 .

2. Rata-rata (mean) yang diperoleh dari hasil penelitian ini yaitu sebesar 54,333.

3. Masyarakat yang melakukan olahraga berenang di dasarkan pada aspek perasaan berada pada presentase $32.85 \%$.

4. Masyarakat yang melakukan olahraga berenang di dasarkan pada aspek motiv berada pada presentase $35.75 \%$

5. Masyarakat yang melakukan olahraga berenang di dasarkan pada aspek harapan berada pada presentase $31.40 \%$

Berdasarkan presentase jawaban per item soal dan indikator aspek persepsi masyarakat, aspek persepsi masyarakat yang paling tinggi adalah aspek motif masyarakat dengan presentase $35.75 \%$. Fenomena-fenomena di lapangan yang menunjukkan motif masyarakatlah yang mendorong masyarakat untuk melakukan olahraga berenang di masa covid - 19 diantaranya didasari dengan keinginan untuk hidup sehat di masa covid - 19, juga keinginan untuk mengisi waktu luang dengan berolahraga berenang di masa covid 19, dan untuk menjadi contoh bagi masyarakat lain untuk menerapkan pola hidup sehat di masa covid - 19. Dengan berolahraga maka peredaran darah akan lancar yang berguna 
untuk kesehatan jantung serta dapat meningkatkan konsentrasi. Berolahraga merupakan salah satu aspek penting dalam membentuk tubuh yang sehat dan bugar. Olahraga perlu dilakukan secara teratur dalam durasi waktu tertentu. Selain itu, olahraga yang dilakukan tidak harus membuat tubuh melakukan hal yang berat. Olahraga juga bisa dilakukan dengan melakukan beberapa jenis gerakan ringan, santai dan menyenangkan.

Kemudian aspek persepsi masyarakat yang paling rendah adalah aspek harapan masyarakat dengan presentase $31.40 \%$. Harapan masyarakat ketika melakukan olahraga berenang di masa covid - 19 cukuplah beragam. Namun seringkali harapan tidak bisa diwujudkan dengan mudah, beberapa harapan yang ada di masyarakat sehingga masyarakat melakukan olahraga berenang di masa covid - 19 adalah harapan untuk agar tubuh tetap sehat dan terjaga dari penyakit, terutama dari covid 19, dengan berenang masyarakat dapat terus sehat di masa covid -19 , olahraga renang bisa membuat tubuh masyarakat menjadi atletis. Akan tetapi terkadang realita di lapangan seringkali menunjukkan hasil yang tidak sesuai dengan apa yang diharapkan oleh masyarakat. Hal ini bisa disebabkan oleh hal - hal lain yang tidak diperhatikan oleh masyarakat itu sendiri. Seperti harapan untuk hidup sehat namun masyarakat tidak menjalankan pola tidur yang teratur atau sering kali khususnya anak muda jam tidurnya tidak teratur karena dipengaruhi oleh aktivitas lain yang dijalankannya hingga larut malam. Kemudian harapan untuk membuat tubuh menjadi atletis namun masyarakat tidak menjalankan pola makan yang sehat dan bergizi. Menjalani pola makan sehat merupakan cara termudah untuk menjaga kebugaran badan dan mencegah tubuh terserang dari penyakit. Menjaga asupan makanan dan melakukan aktivitas fisik merupakan pondasi untuk memiliki tubuh yang sehat. Pola hidup sehat perlu diterapkan sejak awal agar memberikan dampak positif bagi tubuh. Banyak hal yang tanpa disadari justru jauh dari kebiasaan pola hidup sehat. Malas melakukan aktivitas fisik karena sudah dalam zona nyaman, mengonsumsi makanan cepat saji karena terbatasnya waktu, terlalu banyak bergadang karena pekerjaan atau bahkan hal yang tidak penting, adalah beberapa contoh pola hidup yang tidak sehat yang terkadang kita tidak sadari lakukan(Nathaniel et al., 2018).

Menurut dalam jurnal Amiruddin 2010: Persepsi Orang Tua Siswa Terhadap Olahraga Renang di Sekolah Berdasarkan hasil penelitian dapat diambil beberapa kesimpulan yaitu (1) orang tua siswa sangat setuju olahraga renang dilaksanakan di sekolah karena selain untuk ilmu juga untuk perkembangan olahraga di masan mendatang, (2) berkaitan dengan syari'at Islam, orang tua siswa mengatakan perlu adanya pakaian renang yang muslimah dan pemisahan kolam renang antara pria dan wanita. 
Selain itu diungkapkan dalam jurnal menurut Nanda Syahputral, John Arwandi 2019 Persepsi remaja terhadap olahraga renang yaitu, olahraga renang merupakan olahraga yang menarik untuk dilakukan dalam hal olahraga rekreasi. Orang tua lebih memilih olahraga renang karena anak-anak sangat menyukai aktifitasair serta dampak olahraga renang bagi kesehatan anak-anak juga sangat baik yaituuntuk kebugaran dan pergerakan banyak otot pada tubuh anak. Selain itu menurut lansia olahraga renang menjadi kegitan terapi pada lansia yang menderita penyakit syaraf terjepit dan perbaikan tulang belakang.

\section{KESIMPULAN}

Berdasarkan hasil analisis dan pembahasan data, penulis memperoleh kesimpulan yang dapat diambil dari penelitian ini. Dari hasil penelitian menunjukkan bahwa adanya persepsi masyarakat mengenai olahraga berenang di masa covid -19 . Hal ini membuktikan bahwa masih adanya suatu dorongan yang membuat masyarakat berolahraga berenang walaupun masih ( 164 onidisi pandemi covid - 19. Rasa khawatir untuk melakukan olahraga berenang a1 masa covid - 19 memang masih ada di masyarakat. Karena tidak bisa dipungkiri di dalam keadaan pandemi covid -19 masyarakat tidak bisa seenaknya saja untuk menjalankan aktivitas di luar rumah. Khususnya ketika menjalankan aktivitas yang berada di tempat umum yang kita tidak tahu kondisi akan bertemu dengan siapa saja, apakah orang tersebut sehat atau tidak sehat, apakah orang lain tersebut membawa virus atau tidak. Namun hal ini bisa masyarakat tanggulangi dengan cara tetap menjaga protokol kesehatan yang pemerintah sudah himbaukkan kepada masyarakat. Motif adalah aspek masyarakat yang paling tinggi dengan presentase $35.75 \%$. Fenomena-fenomena di lapangan yang menunjukkan motif masyarakatlah yang mendorong masyarakat untuk melakukan olahraga berenang di masa covid - 19 diantaranya didasari dengan keinginan untuk hidup sehat di masa covid - 19, juga keinginan untuk mengisi waktu luang dengan berolahraga berenang di masa covid 19, dan untuk menjadi contoh bagi masyarakat lain untuk menerapkan pola hidup sehat di masa covid -19 .

\section{DAFTAR PUSTAKA}

Abdul Rohman, Asri Budiarto, W. T. (2019). PERANCANGAN PUSAT AQUATIC CENTRE DENGAN PENDEKATAN ARSITEKTUR ORGANIK DI BOGOR Abdul. 02(02), 93-99.

Amiruddin 2010: Persepsi Orang Tua Siswa Terhadap Olahraga Renang di Sekolah 
Anggraini, W., Puspitasari, M. R., Ramadhani, R., Atmaja, D., \& Sugihantoro, H. (2020). Pengaruh Pemberian Edukasi Terhadap Tingkat Pengetahuan Pasien Rawat Jalan Tentang Penggunaan Antibiotik Di RSUD Kanjuruhan Kabupaten Malang. 6(1), $57-62$

Davies, P. D. O. (2002). Multi-drug resistant tuberculosis. CPD Infection, 3(1), 9-12.

Dewan, P. U., Usia, K., Keberagaman, D. A. N., \& Tulung, J. E. (2018). TERHADAP KINERJA KEUANGAN BANK PEMBANGUNAN DAERAH DI SELURUH INDONESIA BUKU 2 TAHUN 2014-2016 EFFECT OF BOARD SIZE, DIVERSITY OF AGE AND GENDER DIVERSITY ON FINANCIAL PERFORMANCE OF REGIONAL DEVELOPMENT BANKS IN ALL INDONESIA BOOK 2 YEAR. 6(4), 2628-2637.

Ishak, M., Hasmarita, S., \& Afandi Harja, A. (2020). Hubungan Motor Ability Dengan Hasil Keterampilan Renang Gaya Punggung. Jurnal Master Penjas \& Olahraga, l(1), 39-46. https://doi.org/10.37742/jmpo.v1i1.6

Ishak, M. (2017). Gaya Mengajar Otoriter Dan Demokratis Terhadap Hasil Belajar Renang Gaya Bebas. Jurnal Pendidikan Jasmani Dan Olahraga, 2(1), 94. https://doi.org/10.17509/jpjo.v2i1.6405

Issom, F. L., \& Putra, P. P. C. (2018). Gambaran Body Image Pada Atlet Remaja Di Sekolah Smp/Sma Negeri Ragunan Jakarta. JPPP - Jurnal Penelitian Dan Nathaniel, A., Sejati, G. P., Perdana, K. K., Lumbantobing, R. D. P., \& Heryandini, S. (2018). Perilaku Profesional Terhadap Pola Makan Sehat. Indonesian Business Review, 1(2), 186-200. https://doi.org/10.21632/ibr.1.2.186-200

Kurniawan, Y. E. (2017). Olahraga Dalam Pandangan Islam. Jurnal Olahraga Indragiri, 1(1), 1-14Pengukuran Psikologi, 7(1), 36-45. https://doi.org/10.21009/jppp.071.05

Nanda Syahputra1, John Arwandi 2019_Persepsi Masyarakat Kota Padang Terhadap Olahraga Renang di Kota Padang

Nawiruddin.M. (2017). Dampak Keberadaan Perkebunan Kelapa Sawit dalam Peningkatan Pendapatan Masyarakat di Kecamatan Long Kali Kabupaten Paser. Jurnal Ilmu Pemerintahan, 5(1), 1-14.

Noveri, I., Pembangunan, K. P., Pemerintahan, P. I., Negeri, U. I., \& Saifuddin, S. T. (2017). DIDIK DIAN UMAR. 1.

Pane, B. S. (2015). Peranan Olahraga Dalam Meningkatkan Kesehatan. Jurnal Pengabdian Kepada Masyarakat, 21(79), 1-4. https://jurnal.unimed.ac.id/2012/index.php/jpkm/article/view/4646

Pratiwi, I. (2015). SEKOLAH RENANG DI KOTA SEMARANG DENGAN PENEKANAN DESIGN SUSTAINABLE ARCHITECTURE Isna. Journal of Architecture, 4(2), 1-9

Ramadani, R. F. (2014). PERSEPSI MASYARAKAT TERHADAP KUALITAS PELAYANAN PUBLIK PADA BAGIAN ADMINISTRASI KESEJAHTERAAN RAKYAT PEMERINTAH KABUPATEN GUNUNGKIDUL DIY. $c$.

Smail, A. (2018). Pengembangan Instrumen Kecerdasan Naturalis Anak Usia Dini Di Kabupaten Luwu Timur Provinsi Sulawesi Selatan. Jurnal Evaluasi Pendidikan, 
$9(1), 16-29$.

Sendow, E. M. M. L. K. G. (2017). Pengaruh Budaya Organisasi, Kepemimpinan, Dan Lingkungan Kerja Terhadap Kinerja Karyawan Pt. Telkom, Tbk Manado. Jurnal EMBA: Jurnal Riset Ekonomi, Manajemen, Bisnis Dan Akuntansi, 5(3), 4025-4034. https://doi.org/10.35794/emba.v5i3.18286

Winarno, M. . (2013). Metodelogi Penelitian Penjas (kedua).

Zaluchu, S. E. (2020). Di Dalam Penelitian Agama. Jurnal, 4, 28-38. 